\title{
INDEX OF AUTHORS
}

$\begin{array}{llll}\text { Aldrich, D. T. A. . . } & \ldots & \ldots & 9\end{array}$

Amoroso, E. C. $\quad \ldots \quad \quad \ldots \quad \quad \ldots \quad 51$

$\begin{array}{lllll}\text { Barker, A. S. } & \text {.. } & \text {. } & \text {. } & 14\end{array}$

Bellis, D. B. $\quad \ldots \quad \ldots \quad \ldots 98$

Blaxter, K. L. $\quad$.. $\quad \ldots \quad \quad \ldots \quad 52$

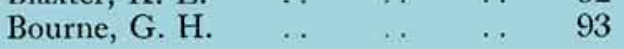

Lane-Petter, W. $\quad \ldots \quad \quad \ldots \quad \ldots \quad 59$

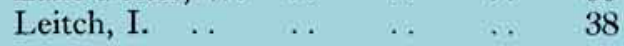

$\begin{array}{llllll}\text { Cassidy, J. . . } & \ldots & \ldots & \ldots & 63\end{array}$

Cuthbertson, W. F. J. $\quad \ldots \quad$.. 70

McGillivray, W. A. $\quad$. $\quad$. $\quad 30$

$\begin{array}{lllll}\text { Davies, W. } & \ldots & \ldots & \ldots & 1\end{array}$

$\begin{array}{lllll}\text { Garry, R. C. } & \text {. } & \text {. } & \text {. } & 37\end{array}$

Head, M. J... $\quad$. $\quad$. $\quad \ldots \quad 25$

Holmes, W. $\quad \cdots \quad 9$

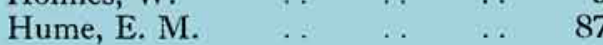

$\begin{array}{lllll}\text { Paterson, J. S. } & \ldots & \ldots & \ldots & 83\end{array}$

Raymond, W. F. .. $\quad \ldots \quad$. $\quad 20$

$\begin{array}{lllll}\text { Rook, J. A. F. } & \text {. } & \text {. } & \ldots & 25\end{array}$

$\begin{array}{lllll}\text { Scott, P. P. . . . } & \ldots & \ldots & 77\end{array}$

$\begin{array}{llll}\text { Thompson, S. Y. } & \text {. } & \ldots & 30\end{array}$

Thomson, A. M. .. $\quad$. $\quad \ldots \quad \ldots \quad 45$

Weeks, C. G. $\quad$. $\quad \ldots \quad \ldots 66$

\section{FORTHCOMING ISSUE}

It is hoped to publish in the next issue of the Proceedings of The Nutrition Society reports of symposia on Man's Need for Water (23 March 1957) and on Clean Food (20 April 1957) and abstracts of communications to be presented at the Open Scientific Meetings on 3 February and 3 May 1957. 


\title{
CONTENTS OF VOLUME 16, No. 1, 1957
}

(All rights reserved)

\section{SYMPOSIUM PROCEEDINGS}

\author{
One Hundred and Third Scientific Meeting \\ GRASSLAND AND THE FEEDING OF LIVESTOCK
}

The grassland environment. By William Davies

PAGE

Nitrogenous fertilizers and the production of crops and grass. By W. Holmes and D. T. A. ALDRICH

Fertilizer nitrogen and milk production from grassland. A review of experience on $\begin{array}{lllllllll}\text { commercial farms. By A. S. BARKER } & \ldots & \ldots & \ldots & \ldots & \ldots & \ldots & 14\end{array}$

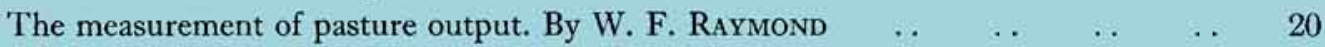

Some effects of spring grass on rumen digestion and the metabolism of the dairy

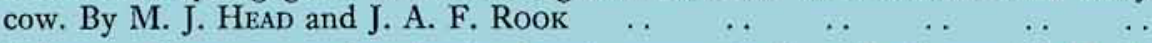

The influence of pasture on the vitamin A and carotene in the milk of cows. By W. A. MCGILlivRAY and S. Y. THOMPSON

\section{One Hundred and Fourth Scientific Meeting}

\section{NUTRITION IN PREGNANCY}

Chairman's introductory remarks. By $\begin{array}{llllllll}\text { R. C. GARRY } & \ldots & \ldots & \ldots & \ldots & \ldots\end{array}$

Changing concepts in the nutritional physiology of human pregnancy. By IsaBeLLA LEITCH .. $\quad \ldots \quad$.

Technique and perspective in clinical and dietary studies of human pregnancy. By

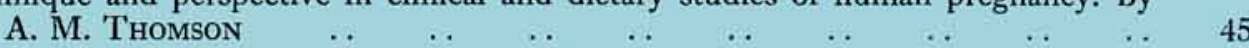

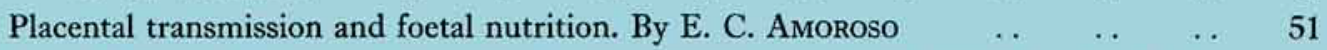

The effects of defective nutrition during pregnancy in farm livestock. By K. L. BLAXTER. .

\section{One Hundred and Fifth Scientific Meeting \\ THE NUTRITION OF LABORATORY ANIMALS}

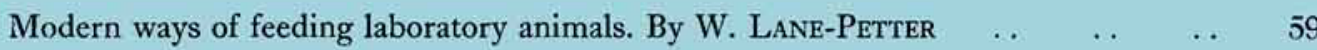

The commercial manufacture of compressed diets for laboratory animals. By J. CASSIDY

The assessment of the diets of laboratory animals. By GwENDOLINE G. WeEKs .

Nutrient requirements of rats and mice. By W. F. J. CuthBertson .. $\quad \ldots \quad \ldots$

Problems encountered in studying the nutrition of the cat (Felis catus Linn.). By

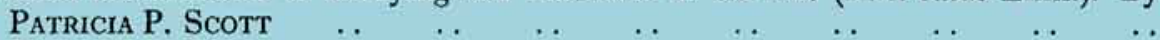

The role of an adequate diet in the production of healthy guinea-pigs. By J. STUART Paterson E. M. Hume

$\begin{array}{lllllllllll}\text { Monkey welfare. By E. M. Hume } & \ldots & \ldots & \ldots & \ldots & \ldots & \ldots & \ldots & 87\end{array}$

Some aspects of the feeding of dogs and other carnivora. By G. H. Bourne $\quad \ldots \quad 93$

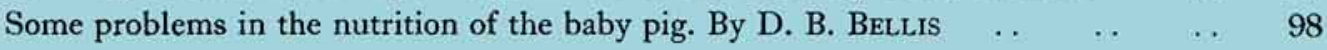

